\title{
Competition between juvenile striped bass and bluefish: resource partitioning and growth rate
}

\author{
Jeffrey A. Buckel ${ }^{1, *}$, Kim A. McKown ${ }^{2}$ \\ ${ }^{1}$ Department of Zoology, Center for Marine Sciences and Technology, North Carolina State University, 303 College Circle, \\ Morehead City, North Carolina 28557, USA \\ ${ }^{2}$ New York State Department of Environmental Conservation, Anadromous Fish Unit, 205 Belle Meade Road, \\ East Setauket, New York 11733, USA
}

\begin{abstract}
The potential for competition to influence the population dynamics of bluefish Pomatomus saltatrix and striped bass Morone saxatilis through interactions at the juvenile stage was examined. Habitat and diet utilization were compared between juvenile striped bass and bluefish in $3 \mathrm{New}$ York Bight marine embayments. Juvenile bluefish and striped bass were seldom captured together during the summer and early fall, suggesting low habitat overlap at the scale of a beach seine haul. Diet overlap was also low; age-0 bluefish (spring- and summer-spawned cohorts) had a more piscivorous diet than age-0 and age-1 striped bass. A 60d laboratory growth experiment tested for interference competition between age-0 bluefish (spring-spawned) and age-1 striped bass fed fish prey in mixed- and single-species treatments. In the growth experiment, bluefish grew significantly faster than striped bass; however, within a species, there was no significant difference in growth between the mixed- and single-species treatments. Additionally, long-term field-monitoring data showed that annual estimates of growth rate for bluefish and striped bass were not correlated with annual estimates of their potential competitor's density. These field and laboratory data provide no evidence for competitive interactions between juvenile striped bass and bluefish.
\end{abstract}

KEY WORDS: Interspecific competition $\cdot$ Resource partitioning $\cdot$ Pomatomus saltatrix $\cdot$ Morone saxatilis Resale or republication not permitted without written consent of the publisher

\section{INTRODUCTION}

Competition is known to influence spatial distribution (Werner \& Hall 1976, Hixon 1980, Robertson 1995), prey utilization (Werner \& Hall 1976, Persson 1987), growth (Werner \& Hall 1976, Prout et al. 1990, Olson et al. 1995, Davis \& Todd 1998) and survivorship (Bystroem et al. 1998) in fishes. Additionally, interspecific competition has been found to cause bottlenecks in recruitment for some freshwater fishes. For example, Persson \& Greenberg (1990) found that juvenile perch Perca fluviatilis and roach Rutilus rutilus compete for zooplankton resources; roach dominate the interaction and limit recruitment in perch. The compe-

*E-mail: jeffrey_buckel@ncsu.edu tition studies described above were conducted on freshwater fishes and (or) on fishes that are fairly siteattached. In contrast, competition in marine pelagic fishes has not been studied as extensively. This is largely due to the difficulties of monitoring these fishes in open marine systems.

Bluefish Pomatomus saltatrix and striped bass Morone saxatilis juveniles provide an opportunity for testing for competition between 2 pelagic marine fish species during their overlap in semi-enclosed bays for several months during summer and fall. Biotic interactions between bluefish and striped bass have been hypothesized to explain opposite trends in landings data (see Fig. 1 and Anonymous 1998). Bluefish and striped bass are important resource species and funding was appropriated by the United States Congress to obtain a better understanding of their popula- 
tion dynamics (see www.house.gov/resources/106cong/ fisheries/00apr28/deluca.htm). Both species have complex life histories and size-structured populations. Various stages are sympatric and allopatric during their ontogeny with overlap occurring when there are small and large differences in body size.

Striped bass are anadromous, with egg and larval stages occurring in freshwater/upper estuarine habitats. Juvenile striped bass in the Hudson River estuary (and other estuarine systems on the US east coast) move into higher-salinity waters during their first year of life. By age-1, striped bass from the Hudson River estuary have moved into marine embayments associated with western Long Island and Staten Island, New York (see Fig. 2); some age-0 striped bass also utilize these bays during late summer (McKown et al. 1999). Bluefish are oceanic spawners but have juvenile stages that utilize nearshore and estuarine habitats. There are generally 2 cohorts of juvenile bluefish that move into New York Bight embayments: juveniles from a spring spawning-event recruit in June while those spawned in early- to mid-summer recruit in August to September (McBride \& Conover 1991; age-0 bluefish will be referred to as spring- and summer-spawned herein).

Spring-spawned bluefish and age-1 striped bass first occur in sympatry around mid- to late-June in estuaries and coastal bays of the New York Bight (McKown et al. 1999). At this time, spring-spawned bluefish are smaller than age-1 striped bass. However, springspawned bluefish attain sizes that are similar to age-1 striped bass by the end of summer. Age-0 striped bass and summer-spawned bluefish overlap in size while sympatric in these embayments in late-summer through fall; summer-spawned bluefish are smaller than age-1 striped bass during this time period (McKown et al. 1999).

We hypothesized that competitive interactions during the juvenile stage may ultimately influence the population dynamics of adult striped bass and bluefish. The 2 major systems that provide striped bass to the coastal adult population are Chesapeake Bay and the Hudson River estuary (Berggren \& Lieberman 1978, Fabrizio 1987, Waldman et al. 1997). Hartman \& Brandt (1995) examined the diet overlap of striped bass and bluefish juveniles in Chesapeake Bay. They found little evidence for diet overlap between age-0 bluefish and age- 0 or age- 1 striped bass. Striped bass diets were dominated by invertebrates whereas bluefish diet included mostly fish prey. This finding may not hold true for other estuarine systems on the east coast of the US where bluefish and striped bass juveniles co-occur. For example, age-1 striped bass diets were dominated by fish in Albemarle Sound, North Carolina (Manooch 1973), suggesting a potential for diet overlap with bluefish. Diet overlap data do not exist for

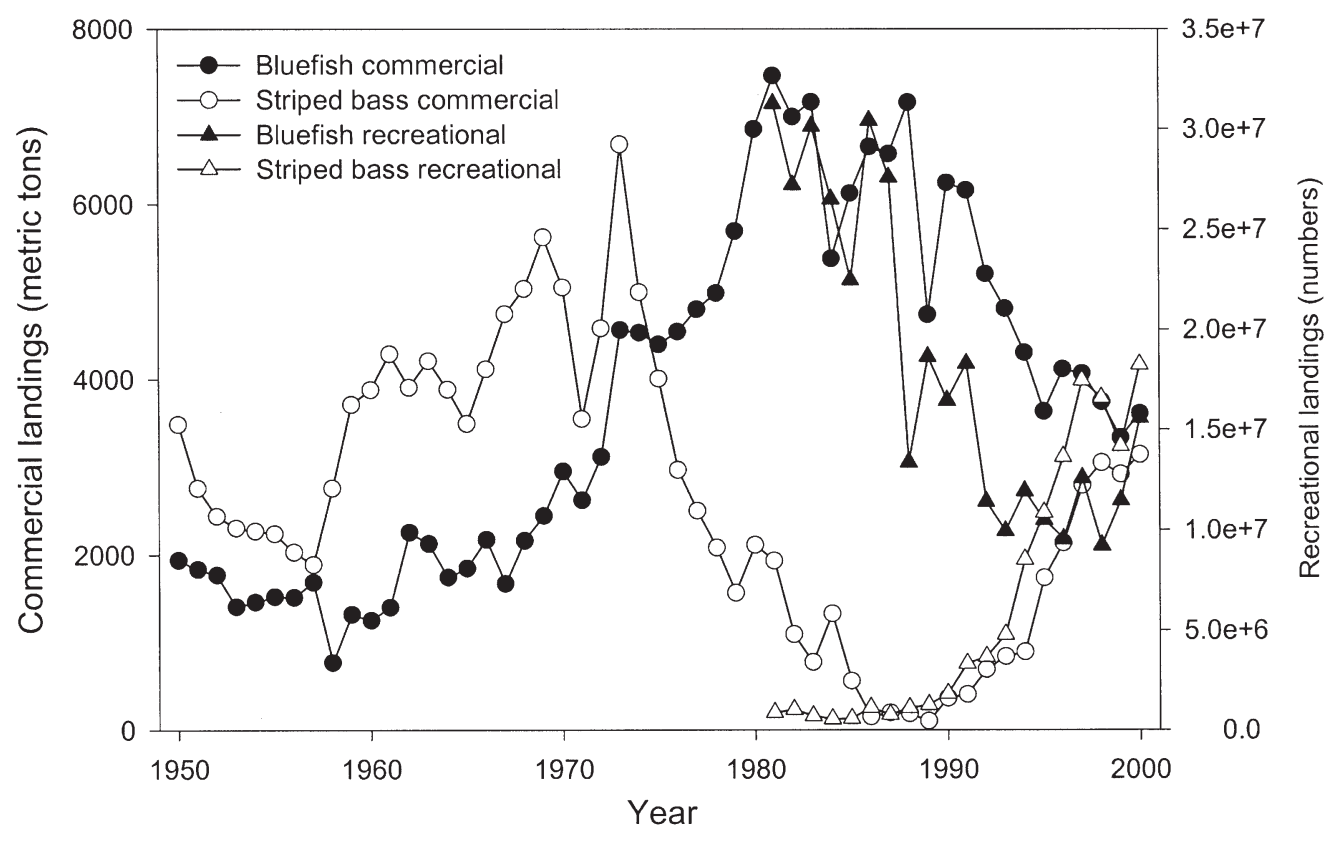

Fig. 1. Annual commercial and recreational fishery landings of bluefish Pomatomus saltatrix and striped bass Morone saxatilis on the US east coast. (Commercial landings, see: www.st.nmfs.gov/st1/commercial/landings/annual_landings.html; recreational landings, see: www.st.nmfs.gov/st1/recreational/queries/catch/time_series.html) 
these 2 species in marine embayments that are utilized by striped bass from the Hudson River population. Moreover, no one to our knowledge has used an experimental approach to examine for competition between bluefish and striped bass. Experiments have proven useful in identifying mechanisms underlying patterns of resource use (Ross 1986).

Here, we examine the potential for competition between juvenile striped bass and bluefish using a field and laboratory approach. Habitat and diet overlap between juvenile striped bass and bluefish were determined in New York Bight embayments. A laboratory experiment was conducted to examine growth of spring-spawned bluefish and age-1 striped bass in single- and mixed-species treatments. Additionally, annual estimates of growth rate for bluefish and striped bass were estimated and compared to water temperature and potential competitors' abundance data from long-term field monitoring data.

\section{MATERIALS AND METHODS}

Field resource partitioning. Study area and field sampling: Bi-weekly to monthly collections were made in New York marine embayments during the New York State Department of Environmental Conservation's (NYDEC) age-1 striped bass survey from May to November 1997 and 1998; this survey has been conducted since 1984 (see McKown et al. 1999). Sampling locations were Manhassett Bay $\left(40^{\circ} 50^{\prime} \mathrm{N}, 73^{\circ} 42^{\prime} \mathrm{W}\right)$ /

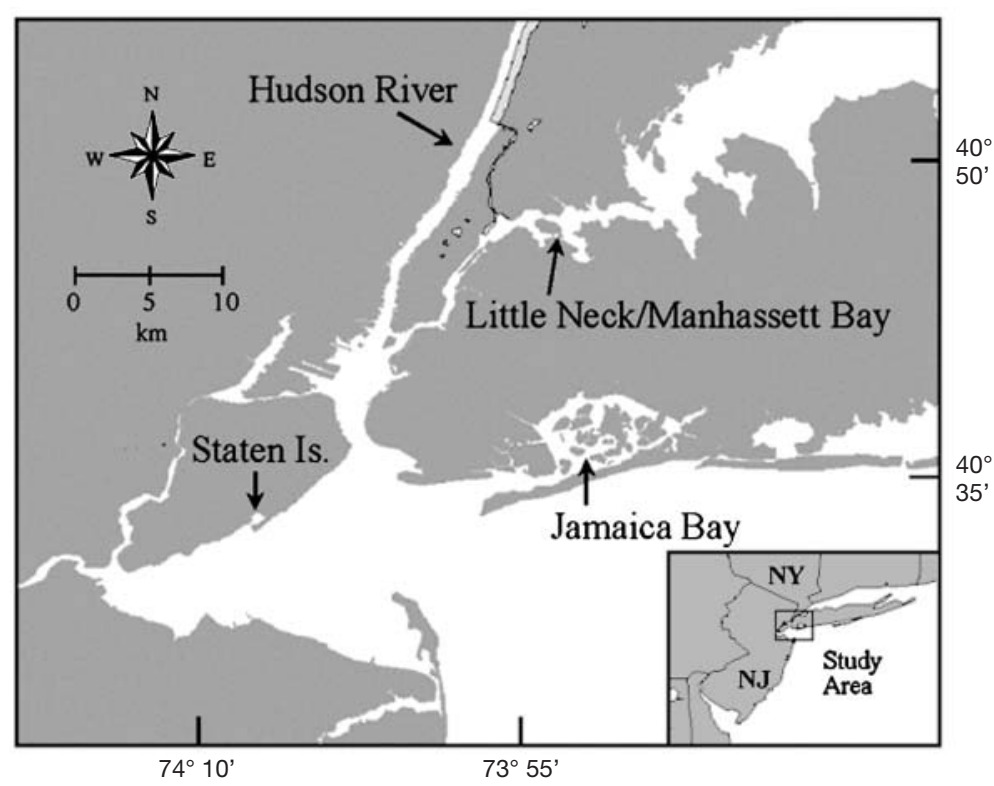

Fig. 2. Embayments in New York Bight where juvenile striped bass Morone saxatilis and bluefish Pomatomus saltatrix were sampled
Little Neck Bay $\left(40^{\circ} 48^{\prime} \mathrm{N}, 73^{\circ} 47^{\prime} \mathrm{W}\right)$ and Jamaica Bay $\left(40^{\circ} 37^{\prime} \mathrm{N}, 73^{\circ} 50^{\prime} \mathrm{W}\right)$ on western Long Island's north and south shore, respectively (Fig. 2). In 1998, we also conducted monthly (May to October) sampling on the south shore of Staten Island $\left(40^{\circ} 32^{\prime} \mathrm{N}, 74^{\circ} 10^{\prime} \mathrm{W}\right)$ (Fig. 2). Mean monthly (May to September) temperatures and salinities at stations within these bays ranged from about 15 to $26^{\circ} \mathrm{C}$ and 22 to 27 ppt in both 1997 and 1998. Bluefish and striped bass were collected with a $61 \times 3 \mathrm{~m}$ beach seine $(13 \mathrm{~mm}$ mesh wings and $6 \mathrm{~mm}$ mesh bag) which was set by boat at fixed stations during daylight hours. Striped bass and bluefish retained for diet analyses were immediately preserved in $10 \%$ buffered formalin.

Food habits: The diets of age-0 and age-1 striped bass were determined in 1997 and 1998 (age was determined with scales which is a validated method for young striped bass: see Secor et al. 1995). In 1998, the diet of spring- and summer-spawned bluefish (cohorts identified by length frequencies) was quantified. Striped bass and bluefish taken for stomach-content analysis were wet weighed $( \pm 1.0 \mathrm{~g})$ and measured for total length, TL $( \pm 1.0 \mathrm{~mm})$. Stomachs were removed and preserved in $10 \%$ buffered formalin. Stomach contents were identified to the lowest possible taxon, enumerated, blotted dry, and weighed $( \pm 0.01 \mathrm{~g})$.

We quantified diet using 2 indices: frequency of occurrence $(\% \mathrm{~F})$ and percent weight $(\% \mathrm{~W})$. Frequency of occurrence was calculated as the number of stomachs in which a prey occurred divided by the total number of stomachs containing food; the weight of each prey type was divided by the total weight of all prey types to calculate prey contribution by weight. Diet of age-1 striped bass and spring-spawned bluefish was quantified by month because they were the main focus of our study and sample sizes were generally larger for these groups. Age-0 striped bass and summer-spawned bluefish diets were pooled by year.

Habitat and diet overlap: Habitat and diet overlap were determined using Schoener's index (Schoener 1970). The index

$$
\alpha=1-0.5\left(\sum_{i=1}^{n}\left|p_{i j}-p_{i k}\right|\right)
$$

determines overlap $(\alpha)$, where $p_{i j}=$ the proportion of the $i$ th resource (beach seine station or prey type) used by species $j$, and $p_{i k}=$ the proportion of the $i$ th resource used by species $k$. Index values can range from 0 to 1 . Values that exceed 0.6 represent 'biologically significant' overlap in resource use 
(Wallace 1981). Besides this arbitrary cutoff, we also compared the observed estimate of overlap to a distribution of expected overlap values based on a null model (random overlap); the distribution of null model data came from 1000 randomizations of the resource data ('scrambled-zeros' randomization algorithm: Winemiller \& Pianka 1990). Simulations were performed using EcoSim software (Gotelli \& Entsminger 2001). The observed overlap value is considered significantly different from the null distribution if the observed value is greater than (or less than) $95 \%$ of the simulated index values $(\mathrm{p}<0.05)$ (Winemiller \& Pianka 1990). We restricted the overlap analysis to bluefish and striped bass cohorts thought to be potential competitors because of similarities in size. Overlap was determined between spring-spawned bluefish and age-1 striped bass and between summer-spawned bluefish and age- 0 striped bass.

The habitat overlap analysis was restricted to dates when both species were captured in the same bay. The proportion, $p$, was calculated using the number of fish (species $j$ or $k$ ) captured at $\operatorname{Stn} i$ divided by the total number of fish (species $j$ or $k$ ) captured at all stations for that particular date and bay combination. Daily estimates of habitat overlap are presented by month and bay for spring-spawned bluefish and age-1 striped bass in 1997 and 1998 and by year for summerspawned bluefish and age-0 striped bass. Data are presented by year for the latter group because of low sample size.

The diet overlap analysis was restricted to those dates in 1998 when stomach-content data were available for both species within a bay. For these bay and date combinations, the proportion by weight of a different prey types found in juvenile bluefish and striped bass stomachs were used to calculate overlap. Prey types used in the analysis were shrimp (sand shrimp Crangon septemspinosa and shore shrimp Palaemonetes spp.), mysids (Neomysis spp.), amphipods (unidentified), polychaete worms (Nereis spp. and Glycera spp.), Atlantic silversides (Menidia menidia), bay anchovy (Anchoa mitchilli), clupeids (Alosa spp. and Brevoortia tyrannus), killifish (Fundulus spp.), and 'other' fishes (for remaining species, see Tables 1 to 4 ). Daily estimates of diet overlap are presented by month and bay for spring-spawned bluefish and age-1 striped bass and by bay for summer-spawned bluefish and age-0 striped bass.

Laboratory growth. There are 2 types of competition. Exploitative competition occurs when a dominant competitor reduces the absolute amount of resource, thus limiting the amount available to a subordinate competitor. Interference competition occurs when a resource becomes limiting to a subordinate because the dominant reduces access to that resource; the absolute resource level does not have to be in short supply for interference competition to occur (Sih 1993, Wootton 1998). There was no evidence from field collections that the absolute amount of prey were limiting (see 'Discussion').

Therefore, a 60d growth experiment was conducted to examine for interference competition in springspawned bluefish and age-1 striped bass. Bluefish and striped bass were collected in the Haverstraw Bay region of the lower Hudson River estuary $\left(41^{\circ} 10^{\prime} \mathrm{N}\right.$, $73^{\circ} 10^{\prime} \mathrm{W}$ ) using beach seines. All fishes were immediately transported to James J. Howard Marine Sciences Laboratory in Sandy Hook, NJ. and brought from lowsalinity ( 3 ppt) to Sandy Hook Bay salinities ( 22 ppt) over $24 \mathrm{~h}$. These fishes were then acclimated in round tanks (1.8 $\mathrm{m}$ diameter, $0.6 \mathrm{~m}$ deep) with flow-through seawater. Striped bass and bluefish were measured ( $\mathrm{TL} \pm 1 \mathrm{~mm})$, weighed $( \pm 0.01 \mathrm{~g})$, and assigned (see following paragraph) to 9 round mesocosms $(2.3 \mathrm{~m}$ diameter, $0.6 \mathrm{~m}$ deep, $2300 \mathrm{l}$ ) with flow-through seawater.

Three treatments were used to examine for interference competition. These were 8 bluefish (singlespecies), 8 striped bass (single-species) and a 4 bluefish $/ 4$ striped bass (mixed-species) treatment. Each treatment was replicated 3 times. Bluefish and striped bass were assigned randomly to either single- or mixed-species treatments. Tank densities $\left(2\right.$ fish $\left.\mathrm{m}^{-2}\right)$ were above bluefish and striped bass densities observed from beach-seine hauls in the various bays $\left(<0.1 \mathrm{fish}^{-2}\right.$ ). Measurements ( $\mathrm{TL}$ in $\mathrm{mm}$ and weight in $\mathrm{g}$ ) were made every $10 \mathrm{~d}$.

The large-sized mesocosms used in this experiment allowed ample space for separation of bluefish and striped bass (in mixed-species tanks) as well as separation between predators and prey. This separation, we hypothesized, would allow behavioral interactions leading to interference between the 2 predator species to occur. If this interference was significant, we would expect growth rate of the subordinate in the mixed tank to be lowered in comparison to that observed within the single-species treatment.

Weighed amounts of live fish prey (Atlantic silverside and killifish Fundulus heteroclitus) were added to all tanks daily; prey in tanks were never depleted completely. These species are the prey of bluefish and striped bass in their native embayments (see Tables 1 to 4). Dead fish prey were removed and weighed daily. Temperature was measured daily. Mortalities in bluefish $(\mathrm{n}=11$, resulting from a monogenetic trematode Microcotyle pomatomi [see Weis 1995] predominantly between Days 30 and 40$)$ and striped bass $(n=1)$ were replaced with fin-clipped individuals of similar size from a laboratory-acclimated population. In this way, growth of the original fishes could be monitored sepa- 
rately from new additions; growth data from new additions were not included in the final analysis. The purpose of these additions was to keep density-dependent influences on growth rate constant throughout the experiment. Mortalities were spread across all bluefish tanks with losses of 2, 4, and 3 from the single-species bluefish tank replicates and losses of 1, 1, and 0 from the mixed-treatment replicates.

Mixed- versus single-species growth was compared using a repeated-measures analysis of variance (ANOVA) with weight as the dependent variable and day as the independent variable. This analysis was performed separately for bluefish and striped bass. Variation in size among individual fish was compared between mixed- and single-species treatment for both bluefish and striped bass at the beginning and end of the experiment using the Levene test.

Ingestion rates of fishes in the mixed- and singlespecies treatments were compared. Absolute ingestion rate was calculated every $10 \mathrm{~d}$ by determining the amount of food eaten by the fishes in a tank and dividing by the number of fishes. Data are presented as $\mathrm{g}$ food fish ${ }^{-1} \mathrm{~d}^{-1}$. Bluefish and striped bass ingestion rates could not be determined separately in the mixedspecies treatment. Absolute ingestion rate of the mixed-species treatment was calculated as above and represents an 'average' of striped bass and bluefish ingestion. For comparison to these 'average' ingestion rate values, the mean of bluefish and striped bass ingestion rates from the single-species treatment values were calculated (i.e. 'additive' rates). Values of 'average' ingestion that are higher or lower than the 'additive' ingestion would be suggestive of interactions between the 2 species.

Relationship between field estimates of growth rate, abundance, and water temperature. Annual estimates of the growth rate of age-1 striped bass and spring-spawned bluefish were determined for 1986 to 1998 (bluefish size data were not collected in 1984 and 1985) from data collected during NYDEC beachseine monitoring of western Long Island bays. Sampling has occurred from May through August in all years. Growth rate $\left(\mathrm{mm} \mathrm{d}^{-1}\right)$ of striped bass and bluefish was estimated as the slope of a least-squares regression fit of fish length (TL) on date of capture. An index of abundance was determined as the geometric mean catch-per-unit-effort (CPUE) for both striped bass (May to August) and bluefish (July to August) by year. The effect of the heterospecific's abundance on growth rate was examined after 2 other factors were also taken into account; these were water temperature and conspecific abundance. A multiple regression analysis with age-1 striped bass growth rate as the dependent variable and water temperature (mean of monthly means for May, June, July, and
August), striped bass density, and bluefish density as independent variables was performed. Similarly, the influence of water temperature (mean of monthly means for July and August) bluefish density, and striped bass density on annual estimates of springspawned bluefish growth rate was examined using the same analysis.

\section{RESULTS}

\section{Field resource partitioning}

\section{Food habits}

A total of 602 juvenile striped bass were examined for dietary analyses from 1997 and 1998 collections. Of these, 224 were age- 0 striped bass $(1997=100 ; 1998=$ $124)$ and 378 were age-1 striped bass $(1997=109$; $1998=269$ ). In 1998, a total of 208 young-of-the-year bluefish (spring-spawned $=147$; summer-spawned $=$ 61 ) were examined for gut contents.

Diets of age- 0 and age- 1 striped bass were dominated by sand shrimp (Crangon septemspinosa) in 1997 and 1998 (Tables 1 to 3). Other important prey types included mysids, amphipods, horseshoe crab eggs/juveniles, and polychaete worms (mostly Nereis spp.). Fish prey (Atlantic silversides, killifish, and bay anchovy) became an important prey item of age-1 striped bass starting in mid-summer and fall (Tables 1 $\& 2$ ); these same fish prey made up 25 to $30 \%$ (by weight) of age-0 striped bass diets in 1997 and 1998.

In 1998, the spring- and summer-spawned bluefish diet was dominated by fish prey although their diets included some invertebrate prey (Table 4). Important fish prey included Atlantic silversides, bay anchovy, and Atlantic menhaden.

\section{Habitat and diet overlap}

Habitat and diet overlap were examined when there were both small and large differences in bluefish and striped bass body size. Age-1 striped bass collected in May averaged $121 \mathrm{~mm}$ TL (range $=77$ to $261 \mathrm{~mm}$ ) prior to bluefish entry, and by fall averaged $>200 \mathrm{~mm}$ TL (range $=164$ to $296 \mathrm{~mm}$ ) (Tables $1 \& 2$ ). Springspawned bluefish recruited to bays in late June when their size $(\sim 70 \mathrm{~mm}$, range $=51$ to 90$)$ was smaller than that of age-1 striped bass, and by fall this cohort had reached sizes (TL $=176 \mathrm{~mm}$, range 155 to 234) that overlapped with age-1 striped bass (Table 4). Age-0 striped bass were captured in September and October of 1997 (90 to $157 \mathrm{~mm} \mathrm{TL}$ ) and August through October of 1998 (39 to $156 \mathrm{~mm} \mathrm{TL}$ ); this time period overlaps 
with the presence of similar-sized summer-spawned bluefish (42 to $152 \mathrm{~mm}$ TL) (Tables 3 \& 4).

The capture of juvenile bluefish and striped bass in the same beach-seine hauls during the summer was infrequent. Habitat overlap of spring-spawned bluefish and age- 1 striped bass was low $(\alpha<0.6)$ during the summer months, with high overlap $(\alpha>0.6)$ occurring predominantly in October of 1997 and 1998 (Fig. 3A). Of 18 null-model tests with these data, in July and August 7 out of 9 observed values were below the mean expected, while in September and October 6 out of 9 were above the expected mean. However, none of the observed overlap values were significantly higher or lower than expected, suggesting random overlap. There was no trend in habitat overlap when examined by bay (Fig. 3B).

Values of habitat overlap were low for summerspawned bluefish and age-0 striped bass in both 1997 $(\alpha<0.6)$ and 1998 (6 out of $7 \alpha<0.6)$ (Fig. 3C). Of 10 null model tests with these data, only 1 observed value was significantly higher than expected ( $\mathrm{p}<0.001)$; the remainder were not statistically significant from random.

Diets of juvenile bluefish and striped bass differed. Spring-spawned bluefish and age-1 striped bass diet overlap was low $(\alpha<0.6)$ (Fig. 4A,B). Eleven nullmodel simulations were performed for spring-spawned bluefish and only 1 observed value was significantly higher than expected $(p=0.040)$; the remainder were not statistically significant from random. Diet overlap between summer-spawned bluefish and age-0 striped bass were also below 0.6 during 1998 (Fig. 4C). Out of 6 null-model tests, 5 were not statistically significant from random; the significant observed value was higher than expected $(\mathrm{p}=0.037)$.

\section{Laboratory growth}

The initial mean sizes of bluefish were $16.9 \mathrm{~g}(0.30$ $\mathrm{SE}) 124 \mathrm{~mm} \mathrm{TL}$, and $16.6 \mathrm{~g}(0.22 \mathrm{SE}), 121 \mathrm{~mm}$ TL in the

Table 1. Morone saxatilis. Stomach contents of age-1 striped bass from 1997 beach seine collections in western Long Island. $\%$ F: proportion of stomachs (with food) containing a prey type, \% W: proportion contribution of identifiable prey to diet by weight. TL: total length

\begin{tabular}{|c|c|c|c|c|c|c|}
\hline \multirow[t]{2}{*}{ Prey type } & \multicolumn{2}{|c|}{ Jun } & \multicolumn{2}{|c|}{ Jul/Aug } & \multicolumn{2}{|c|}{ Sep/Oct } \\
\hline & $\% \mathrm{~F}$ & $\% \mathrm{~W}$ & $\% \mathrm{~F}$ & $\% \mathrm{~W}$ & $\% \mathrm{~F}$ & $\% \mathrm{~W}$ \\
\hline \multicolumn{7}{|l|}{ Invertebrates } \\
\hline Sand shrimp & 41.0 & 42.4 & 33.3 & 12.2 & 31.6 & 34.0 \\
\hline Shore shrimp & 2.6 & 1.3 & & & & \\
\hline Mysids & 48.7 & 6.5 & 27.8 & 8.2 & & \\
\hline Amphipods & 41.0 & 4.3 & 22.2 & 0.7 & 5.3 & $<0.1$ \\
\hline Polychaete worms & 38.5 & 28.8 & 22.3 & 6.8 & 21.1 & 15.7 \\
\hline Mya sp. siphons & 2.6 & 1.1 & & & & \\
\hline Lady crab & & & & & 5.3 & 4.0 \\
\hline Blue crab & & & & & 5.3 & 1.1 \\
\hline Copepod & 2.6 & $<0.1$ & & & & \\
\hline Horseshoe crab eggs/juveniles & & & 41.7 & 44.4 & & \\
\hline Unidentified gastropod & 2.6 & 3.5 & & & & \\
\hline Unidentified shrimp remains & 10.3 & 1.8 & 5.6 & 1.1 & & \\
\hline Unidentified crust. remains & 2.6 & 0.1 & & & & \\
\hline Total inverbrates & 100.0 & 89.9 & 77.8 & 73.4 & 47.4 & 54.8 \\
\hline \multicolumn{7}{|l|}{ Fishes } \\
\hline Bay anchovy & & & & & 10.5 & 0.4 \\
\hline Atlantic silverside & & & 30.6 & 18.4 & 15.8 & 15.7 \\
\hline Killifish & & & 11.1 & 3.7 & 21.1 & 23.2 \\
\hline Atlantic tomcod & 2.6 & 5.2 & & & & \\
\hline Three-spined stickleback & 2.6 & 0.3 & & & & \\
\hline Sand lance & 2.6 & 2.9 & & & & \\
\hline Goby & & & & & 5.3 & 1.6 \\
\hline Unidentified fish remains & 10.3 & 0.3 & 25.0 & 1.5 & 21.1 & 4.3 \\
\hline Total fishes & 17.9 & 8.7 & 52.8 & 23.6 & 57.9 & 45.2 \\
\hline Other $^{\mathrm{a}}$ & 5.2 & 1.4 & 2.8 & 3.1 & & \\
\hline Total stomachs analyzed & \multicolumn{2}{|c|}{48} & \multicolumn{2}{|c|}{37} & \multicolumn{2}{|c|}{24} \\
\hline Number containing prey & \multirow{2}{*}{\multicolumn{2}{|c|}{$\begin{array}{c}39 \\
134(4)\end{array}$}} & \multicolumn{2}{|c|}{36} & \multicolumn{2}{|c|}{19} \\
\hline Mean TL (mm) (SE) & & & \multicolumn{2}{|c|}{$152(5)$} & \multicolumn{2}{|c|}{$236(6)$} \\
\hline TL range (mm) & \multicolumn{2}{|c|}{$78-207$} & \multirow{2}{*}{\multicolumn{2}{|c|}{$\begin{array}{c}96-241 \\
39.5(4.6)\end{array}$}} & \multicolumn{2}{|c|}{$164-296$} \\
\hline Mean wt (g) (SE) & \multicolumn{2}{|c|}{$28.3(2.8)$} & & & & \\
\hline
\end{tabular}


Table 2. Morone saxatilis. Stomach contents of age-1 striped bass from 1998 beach seine collections in western Long Island and Staten Island. \% F: proportion of stomachs (with food) containing a prey type, \% W: proportion contribution of identifiable prey to diet by weight. TL: total length

\begin{tabular}{|c|c|c|c|c|c|c|c|c|c|c|}
\hline \multirow[t]{2}{*}{ Prey type } & \multicolumn{2}{|c|}{ May } & \multicolumn{2}{|c|}{ Jun } & \multicolumn{2}{|c|}{ Jul } & \multicolumn{2}{|c|}{ Aug } & \multicolumn{2}{|c|}{ Sep/Oct } \\
\hline & $\% \mathrm{~F}$ & $\% \mathrm{~W}$ & $\% \mathrm{~F}$ & $\% \mathrm{~W}$ & $\% \mathrm{~F}$ & $\% \mathrm{~W}$ & $\% \mathrm{~F}$ & $\% \mathrm{~W}$ & $\% \mathrm{~F}$ & $\% \mathrm{~W}$ \\
\hline \multicolumn{11}{|l|}{ Invertebrates } \\
\hline Sand shrimp & 17.02 & 8.5 & 9.6 & 4.7 & 55.9 & 42.3 & 75.6 & 60.4 & 29.2 & 11.5 \\
\hline Shore shrimp & 4.3 & 3.1 & 4.3 & 2.7 & 2.9 & $<0.1$ & 15.6 & 1.6 & 25.0 & 8.3 \\
\hline Mysids & 17.0 & 29.0 & 30.9 & 18.5 & 32.4 & 19.2 & 4.4 & 1.5 & 8.3 & 0.3 \\
\hline Amphipods & 2.1 & $<0.1$ & 31.9 & 4.7 & 20.6 & 3.4 & & & & \\
\hline Polychaete worms & 49.0 & 15.4 & 32.0 & 32.6 & 8.8 & 2.0 & 4.4 & 0.7 & 4.2 & 3.3 \\
\hline Mya sp. siphons & 10.6 & 0.8 & & & 2.9 & 0.1 & & & 4.2 & 0.6 \\
\hline Lady crab & & & & & & & 6.7 & 4.9 & & \\
\hline Blue crab & & & & & & & 2.2 & 1.6 & & \\
\hline Hermit crab & & & & & & & 2.2 & 0.4 & & \\
\hline Crab zoeae/megalop & & & 23.4 & 6.9 & & & & & & \\
\hline Copepod & & & 5.3 & 0.6 & & & & & & \\
\hline Isopod & 2.1 & 0.3 & & & & & & & & \\
\hline Horseshoe crab eggs/juveniles & 2.1 & 1.2 & 9.6 & 18.0 & & & & & & \\
\hline Ctenophore & & & & & & & & & 4.2 & 1.2 \\
\hline Unidentified shrimp remains & 12.8 & 4.2 & 7.4 & 2.9 & 5.9 & 2.0 & 2.2 & 0.5 & 4.2 & 0.9 \\
\hline Unidentified crust. remains & 6.4 & 1.4 & 23.4 & 2.8 & 8.8 & 1.6 & 4.4 & 0.4 & 20.8 & 4.1 \\
\hline Total invertebrates & 89.4 & 63.9 & 95.7 & 94.4 & 94.1 & 70.6 & 95.6 & 72.0 & 75.0 & 30.2 \\
\hline \multicolumn{11}{|l|}{ Fish } \\
\hline Bay anchovy & 4.3 & 26.1 & & & 2.9 & 0.6 & 6.7 & 4.8 & & \\
\hline Atlantic silverside & & & 5.3 & 4.4 & 14.7 & 15.1 & 20.0 & 12.6 & 8.3 & 11.1 \\
\hline Alosa sp. & & & & & & & 4.4 & 0.4 & & \\
\hline Killifish & & & & & 2.9 & 4.5 & 2.2 & 4.5 & 12.5 & 31.5 \\
\hline Northern kingfish & & & & & & & 6.7 & 3.7 & & \\
\hline Winter flounder & & & & & & & & & 4.2 & 9.9 \\
\hline \multicolumn{11}{|l|}{ Sand lance } \\
\hline Goby & & & & & 2.9 & 3.4 & & & & \\
\hline Unidentified fish remains & 21.3 & 9.6 & 7.4 & 1.3 & 29.4 & 5.7 & 6.7 & 0.5 & 25.0 & 17.2 \\
\hline Total fishes & 23.4 & 35.7 & 12.8 & 5.7 & 47.1 & 29.3 & 33.3 & 26.5 & 37.5 & 69.7 \\
\hline Other $^{a}$ & 2.1 & 0.2 & & & 2.9 & $<0.1$ & 4.4 & 1.6 & & \\
\hline Total stomachs analyzed & \multicolumn{2}{|c|}{62} & \multicolumn{2}{|c|}{100} & \multicolumn{2}{|c|}{35} & \multicolumn{2}{|c|}{48} & \multicolumn{2}{|c|}{24} \\
\hline Number containing prey & \multicolumn{2}{|c|}{47} & \multicolumn{2}{|c|}{94} & \multicolumn{2}{|c|}{34} & \multicolumn{2}{|c|}{45} & \multicolumn{2}{|c|}{16} \\
\hline Mean TL (mm) (SE) & \multicolumn{2}{|c|}{$121(5)$} & \multicolumn{2}{|c|}{$129(2)$} & \multicolumn{2}{|c|}{$144(3)$} & \multicolumn{2}{|c|}{$167(3)$} & \multicolumn{2}{|c|}{$216(5)$} \\
\hline TL range $(\mathrm{mm})$ & \multicolumn{2}{|c|}{$77-261$} & $90-$ & 168 & 101 & 193 & 11 & 210 & 170 & 58 \\
\hline Mean wt (g) (SE) & 23.6 & $(4.5)$ & 25.0 & $(1.2)$ & 34.2 & 2.3) & 47. & 2.9) & 113. & $8.0)$ \\
\hline
\end{tabular}

single- and mixed-species treatments, respectively. Initial mean sizes of striped bass were $14.9 \mathrm{~g}(0.33)$ (115 mm TL) in the single-species tanks and $15.8 \mathrm{~g}$ (0.53) (117 mm TL) in the mixed-species tanks. Values of initital mean weight did not differ within species across treatments (bluefish: Student's $t=0.584, \mathrm{df}=4$, $\mathrm{p}=0.590$; striped bass: Student's $t=1.456, \mathrm{df}=4, \mathrm{p}=$ 0.219). Temperature was relatively stable during the experiment $\left(\right.$ mean $=22^{\circ} \mathrm{C}$, range $=20-23^{\circ} \mathrm{C}$ ).

Bluefish and striped bass grew rapidly over time (Table 5, Fig. 5). However, there were no significant differences in growth between bluefish from the single- and mixed-species treatments; this was also true for striped bass growth in single- versus mixedspecies treatments (Table 5, Fig. 5). The variances among individual fish were calculated by tank; no differences were found between mixed- versus single- species treatments within a species at the beginning or end of the experiment (Levene's test, p values $>0.05$ for all species/time period combinations).

The 'additive' ingestion rates were similar to 'average' ingestion rates throughout the experiment (Fig. 6). Estimates of mean ingestion rate from the mixed-species treatment that deviated the most from 'additive' ingestion (Days 30 to 40 and 40 to 50: Fig. 6) were not significantly different ( $t$-test: $p$ values $>0.05$ ) from 'additive' ingestion values for these periods.

\section{Relationship between field estimates of growth rate, abundance, and water temperature}

Multiple regression analysis revealed that annual estimates of age-1 striped bass growth rate were not 

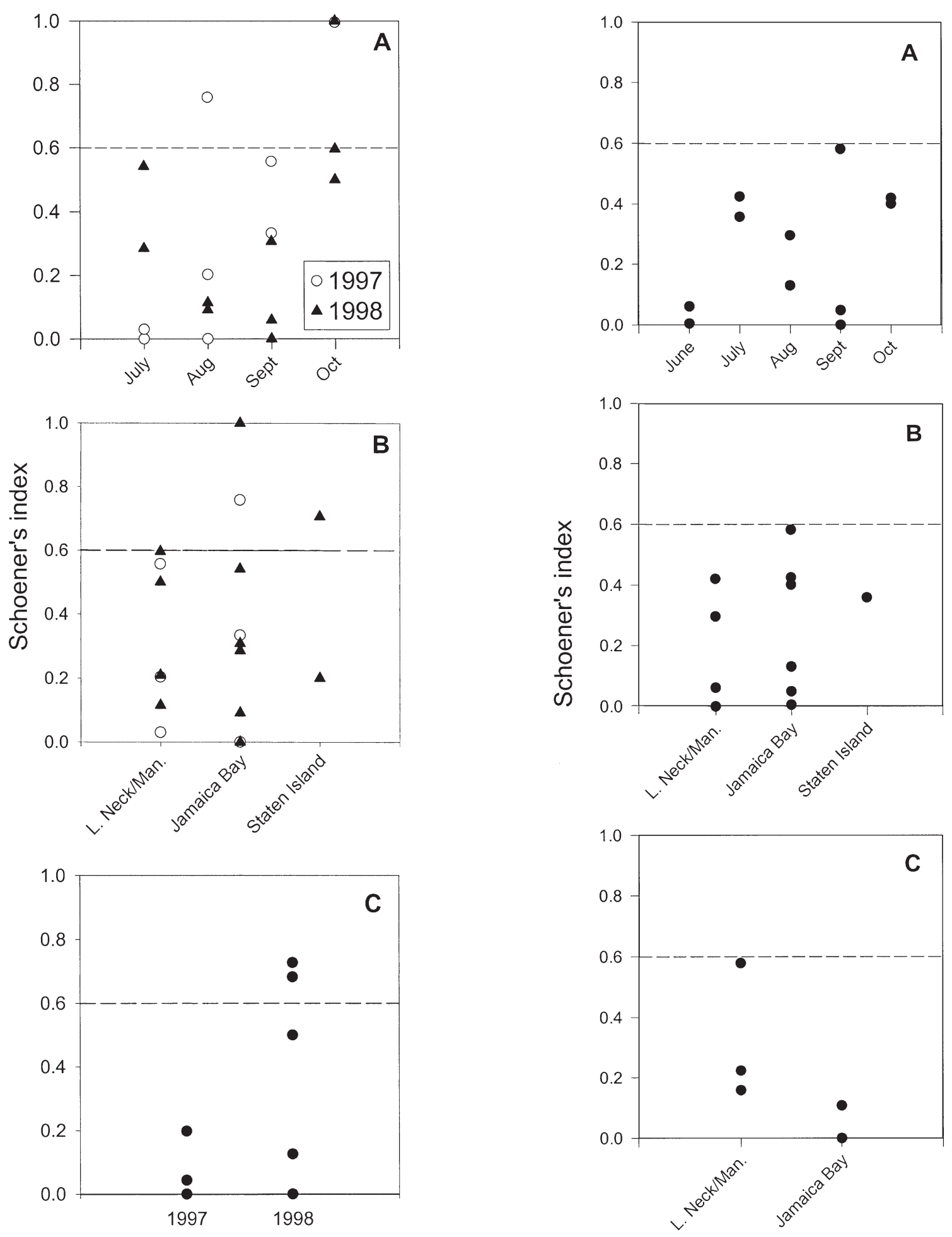

Fig. 3. Pomatomus saltatrix and Morone saxatilis. Values of Schoener's (1970) index for habitat overlap in (A) age-0 bluefish (spring-spawned) and age-1 striped bass by month, (B) age- 0 bluefish (spring-spawned) and age-1 striped bass by bay for 1997 and 1998, and (C) age-0 bluefish (summerspawned) and age-0 striped bass in 1997 and 1998. Values above 0.6 (dashed line) represent significant overlap in

Fig. 4. Pomatomus saltatrix and Morone saxatilis. Values of Schoener's (1970) index for diet overlap in (A) age-0 bluefish (spring-spawned) and age-1 striped bass by month, (B) age-0 bluefish (spring-spawned) and age-1 striped bass by bay, and (C) age-0 bluefish (summer-spawned) and age-0 striped bass by bay. All comparisons are based on 1998 collections. Values above 0.6 (dashed line) represent significant overlap in resource use 
Table 3. Morone saxatilis. Stomach contents of age-0 striped bass from 1997 and 1998 beach seine collections in western Long Island and Staten Island. $\%$ F: proportion of stomachs (with food) containing a prey type, \% W: proportion contribution of identifiable prey to diet by weight. TL: total length

\begin{tabular}{|c|c|c|c|c|}
\hline \multirow{2}{*}{ Prey type } & \multicolumn{2}{|c|}{1997} & \multicolumn{2}{|c|}{1998} \\
\hline & $\% \mathrm{~F}$ & $\% \mathrm{~W}$ & $\% \mathrm{~F}$ & $\% \mathrm{~W}$ \\
\hline \multicolumn{5}{|l|}{ Invertebrates } \\
\hline Sand shrimp & 70.4 & 51.6 & 27.9 & 29.5 \\
\hline Shore shrimp & 8.2 & 4.8 & 10.8 & 23.7 \\
\hline Mysids & 28.6 & 8.9 & 22.5 & 5.1 \\
\hline Amphipods & 5.1 & 0.1 & 36.9 & 6.4 \\
\hline Polychaete worms & 10.2 & 2.8 & 15.3 & 6.7 \\
\hline Mya sp. siphons & 1.0 & $<0.1$ & 0.9 & 0.4 \\
\hline Blue crab & & & 0.9 & 0.1 \\
\hline Unidentified shrimp remains & 10.2 & 1.7 & 3.6 & 1.0 \\
\hline Unidentified crust. remains & & & 7.2 & 1.8 \\
\hline Total invertebrates & 89.8 & 69.9 & 91.0 & 74.7 \\
\hline \multicolumn{5}{|l|}{ Fishes } \\
\hline Bay anchovy & 6.1 & 3.1 & 14.4 & 6.8 \\
\hline Atlantic silverside & 6.1 & 6.1 & 3.6 & 9.4 \\
\hline Killifish & 6.1 & 7.6 & 0.9 & 2.1 \\
\hline Goby & 2.0 & 0.7 & 1.8 & 3.2 \\
\hline Unidentified fish remains & 35.7 & 12.5 & 13.5 & 3.6 \\
\hline Total fishes & 51.0 & 30.0 & 29.7 & 25.1 \\
\hline Other $^{a}$ & 1.0 & 0.1 & & \\
\hline \multicolumn{5}{|l|}{0.4} \\
\hline Total stomachs analyzed & \multicolumn{2}{|c|}{100} & \multicolumn{2}{|c|}{124} \\
\hline Number containing prey & \multirow{2}{*}{\multicolumn{2}{|c|}{$\begin{array}{c}98 \\
121\end{array}$}} & \multicolumn{2}{|c|}{111} \\
\hline Mean TL $(\mathrm{mm})(\mathrm{SE})$ & & & \multicolumn{2}{|c|}{$80.7(3)$} \\
\hline TL Range (mm) & \multicolumn{2}{|c|}{$\begin{array}{l}121(1) \\
90-157\end{array}$} & \multirow{2}{*}{\multicolumn{2}{|c|}{$\begin{array}{c}39-156 \\
8.9(0.9)\end{array}$}} \\
\hline Mean wt (g) (SE) & \multicolumn{2}{|c|}{$18.6(0.7)$} & & \\
\hline
\end{tabular}

competition did not occur between striped bass and bluefish held in mixed-species treatments in a laboratory experiment. Additionally, annual field estimates of growth rate for striped bass and bluefish were not related to their heterospecific's abundance.

\section{Field resource partitioning}

Food habits

The diet data for age-0 and age-1 striped bass presented here are the first for western Long Island and Staten Island bays. These bays serve as a nursery habitat for several age classes of juvenile striped bass from the Hudson River population (McKown et al. 1999).

There were similarities and differences between age-0 striped bass diets in our study compared with past research. The diets of age-0 striped bass included small invertebrate prey (e.g. amphipods, mysids) which was similar to diets of age-0 fish in the Hudson River estuary (Gardinier \& Hoff 1982, Hurst \& Conover 2001) and other mid-Atlantic Bight estuaries (Markle \& Grant 1970, Boynton et al. 1981, Hartman \& Brandt 1995, Cooper et al. 1998). Diets of age-0 striped bass from our

significantly related to mean water temperature, abundance of spring-spawned bluefish, or abundance of age-1 striped bass $\left(\mathrm{R}=0.333, F_{3,9}=0.373, \mathrm{p}=0.775\right)$. Additionally, there was no relationship between annual estimates of bluefish growth rate and mean water temperature, striped bass abundance, or bluefish abundance $\left(\mathrm{R}=0.234, F_{3,9}=0.174, \mathrm{p}=0.911\right)$. The power of the 2 multiple regression tests were relatively high ( $\sim 80$ to $85 \%$ ). Hence, there is no growth rate evidence from the field which is suggestive of inter- or intraspecific competition.

\section{DISCUSSION}

Overall, we found no evidence for competition between juvenile striped bass and bluefish. Habitat and diet overlap in New York Bight marine embayments were generally low. For the majority of the growing season, striped bass and bluefish were not found in similar locations. Diets of juvenile bluefish were dominated by fish prey while striped bass diets were dominated by invertebrate prey. Interference study sites differed from other studies, including the Hudson River estuary, because relatively large invertebrates (e.g. the sand shrimp Crangon septemspinosa) and fishes were important prey items.

The cause of diet differences between age-0 striped bass in the Hudson River estuary and the bays where we sampled could result from several factors. The mean sizes of age-0 fish captured in the bays in midsummer are larger than those in the estuary (McKown et al. 1999). Diet differences may reflect ontogenetic differences. This does not appear to be the case, however, as age- 0 striped bass (from 39 to $90 \mathrm{~mm}$ TL) in 1998 (a year with a large range in age-0 striped bass sizes) ingested amounts of total invertebrates $(120 \% \mathrm{~F}$, $64 \% \mathrm{~W})$ and total fishes $(35 \% \mathrm{~F}, 36 \% \mathrm{~W})$ similar to those ingested by all sizes combined in 1998 (39 to $156 \mathrm{~mm}$ TL: Table 3). One potential reason for the movement of age-0 striped bass into higher salinity habitats may be to exploit larger and possibly higherenergy prey such as decapods and fishes.

Diets of age-1 striped bass included a diverse group of prey and varied by month. Invertebrates (e.g. sand shrimp, polychaete worms, mysids) dominated the diet 
Table 4. Pomatomus saltatrix. Stomach contents of age-0 spring- and summer-spawned bluefish from 1998 beach seine collections in western Long Island and Staten Island. \% F: proportion of stomachs (with food) containing a prey type; \% W: proportion contribution of identifiable prey to diet by weight. TL: total length

\begin{tabular}{|c|c|c|c|c|c|c|c|c|c|c|c|c|}
\hline \multirow[t]{2}{*}{ Prey type } & \multicolumn{2}{|c|}{ Jun } & \multicolumn{2}{|c|}{ Jul } & \multicolumn{2}{|c|}{ Aug } & \multicolumn{2}{|c|}{ Sep } & \multicolumn{2}{|c|}{ Oct } & \multicolumn{2}{|c|}{ Summer-spawned } \\
\hline & $\% \mathrm{~F}$ & $\% \mathrm{~W}$ & $\% \mathrm{~F}$ & $\% \mathrm{~W}$ & $\% \mathrm{~F}$ & $\% \mathrm{~W}$ & $\% \mathrm{~F}$ & $\% \mathrm{~W}$ & $\% \mathrm{~F}$ & $\% \mathrm{~W}$ & $\% \mathrm{~F}$ & $\% \mathrm{~W}$ \\
\hline \multicolumn{13}{|l|}{ Invertebrates } \\
\hline Sand shrimp & 8.1 & 1.1 & 28.6 & 13.8 & 16.7 & 8.6 & & & 7.1 & 1.8 & 10.0 & 2.1 \\
\hline Shore shrimp & & & & & 16.7 & 1.0 & 6.3 & 0.5 & & & 8.0 & 1.0 \\
\hline Mysids & 8.1 & 1.0 & 19.0 & 2.1 & 8.3 & 2.0 & & & 7.1 & 2.1 & 10.0 & 1.8 \\
\hline Amphipods & 5.4 & 6.4 & 9.5 & 1.0 & 8.3 & 0.4 & & & & & & \\
\hline Polychaete worms & 5.4 & 0.3 & & & 8.3 & $<0.1$ & & & & & 2.0 & $<0.1$ \\
\hline Lady crab & & & & & & & 2.1 & 0.2 & & & & \\
\hline Crab zoeae/megalop & & & 28.6 & 5.6 & & & & & & & & \\
\hline Unidentified shrimp larvae & 2.7 & 0.2 & & & & & & & & & & \\
\hline Unidentified shrimp remains & 8.1 & 0.8 & 9.5 & 1.7 & & & & & & & & \\
\hline Unidentified crust. remains & 8.1 & 0.6 & 4.8 & $<0.1$ & & & & & & & 2.0 & $<0.1$ \\
\hline Total invertebrates & 45.9 & 10.4 & 71.4 & 24.2 & 41.7 & 12.0 & 6.3 & 0.7 & 14.3 & 3.9 & 30.0 & 4.9 \\
\hline \multicolumn{13}{|l|}{ Fishes } \\
\hline Bay anchovy & 10.8 & 27.5 & & & 8.3 & 2.7 & 2.1 & 0.1 & 28.6 & 10.1 & 16.0 & 13.9 \\
\hline Atlantic silverside & 51.4 & 49.2 & 19.0 & 30.4 & 25.0 & 14.2 & 16.7 & 17.6 & 21.4 & 28.5 & 6.0 & 7.1 \\
\hline Atlantic menhaden & & & 14.3 & 31.8 & 25.0 & 62.6 & 25.0 & 52.0 & 7.1 & 0.3 & 16.0 & 44.5 \\
\hline Killifish & & & & & & & & & & & 2.0 & 5.7 \\
\hline Black sea bass & & & & & & & & & 7.1 & 0.3 & & \\
\hline Sand lance & & & & & & & & & 7.1 & 0.2 & & \\
\hline Sea robin & & & & & & & & & 14.3 & 0.3 & & \\
\hline Bluefish & & & & & & & 2.1 & 3.7 & & & & \\
\hline Unidentified clupeid & & & & & & & 20.8 & 14.0 & & & & \\
\hline Unidentified fish larvae & & & & & & & & & 21.4 & 17.8 & & \\
\hline Unidentified sciaenid & & & & & & & & & 7.1 & 0.5 & & \\
\hline Unidentified fish remains & 13.5 & 12.6 & 38.1 & 13.4 & 33.3 & 8.4 & 31.3 & 11.8 & 50.0 & 38.2 & 42.0 & 23.9 \\
\hline Total fishes & 75.7 & 89.3 & 66.7 & 75.6 & 75.0 & 87.9 & 97.9 & 99.2 & 100.0 & 96.2 & 80.0 & 95.1 \\
\hline Other $^{a}$ & 2.7 & 0.3 & 4.8 & $<0.1$ & & & 4.2 & $<0.1$ & 7.1 & $<0.1$ & & \\
\hline Total stomachs analyzed & & 2 & 2 & 3 & & 13 & & 52 & 1 & 7 & & 61 \\
\hline Number containing prey & & 7 & 2 & 1 & & 12 & & 48 & 1 & 4 & & 50 \\
\hline Mean TL (mm) (SE) & & (1) & 110 & $(4)$ & 145 & $5(4)$ & 199 & $(2.6)$ & & $5(3)$ & & $9(4)$ \\
\hline TL Range (mm) & 51 & -90 & $73-$ & -134 & $117-$ & -166 & 128 & -258 & 155 & -234 & & -152 \\
\hline Mean wt (g) (SE) & 3.1 & $(0.2)$ & 12.2 & $2(1)$ & 27.6 & $(2.4)$ & 86.8 & $3(3.4)$ & 55.6 & $6(4)$ & $15 .($ & $(1.2)$ \\
\hline
\end{tabular}

until late summer and fall when fishes (e.g. Atlantic silversides, killifish, and bay anchovies) became an increasingly more important part of age-1 striped bass diets. Gardinier \& Hoff (1982) and Hartman \& Brandt

Table 5. Pomatomus saltatrix and Morone saxatilis. Repeated-measures analysis of variance with treatment (single- versus mixed-species) and time as independent variables and weight as dependent variable for bluefish and striped bass

\begin{tabular}{|lcccc|}
\hline Effect & df & SS & $F$ & $p$ \\
\hline Bluefish & & & & \\
Treatment & 1 & 58.11 & 0.43 & 0.549 \\
Time & 6 & 44251.98 & 356.88 & $<0.0001$ \\
Treatment $\times$ Time & 6 & 104.16 & 0.84 & 0.552 \\
Striped bass & & & & \\
Treatment & 1 & 0.003 & 0.0001 & 0.993 \\
Time & 6 & 7743.05 & 418.58 & $<0.0001$ \\
Treatment $\times$ Time & 6 & 7.68 & 0.41 & 0.862 \\
\hline
\end{tabular}

(1995) also found an increased use of fish prey in late summer and fall months for age-1 striped bass in the Hudson River estuary and Chesapeake Bay, respectively. However, Manooch (1973) found that fish prey (clupeids and engraulids) dominated the diets of age-1 striped bass in Albemarle Sound, North Carolina, throughout the growing season. As with age-0 striped bass, these patterns are likely to be driven by a combination of an ontogenetic increase in the ability to capture fish prey and the availability of appropriately sized fish prey.

Several studies have investigated the diets of spring- and summer-spawned bluefish in New York Bight bays (see Buckel \& Conover 1997 for references). In order to characterize diet overlap between bluefish and striped bass, it was necessary 


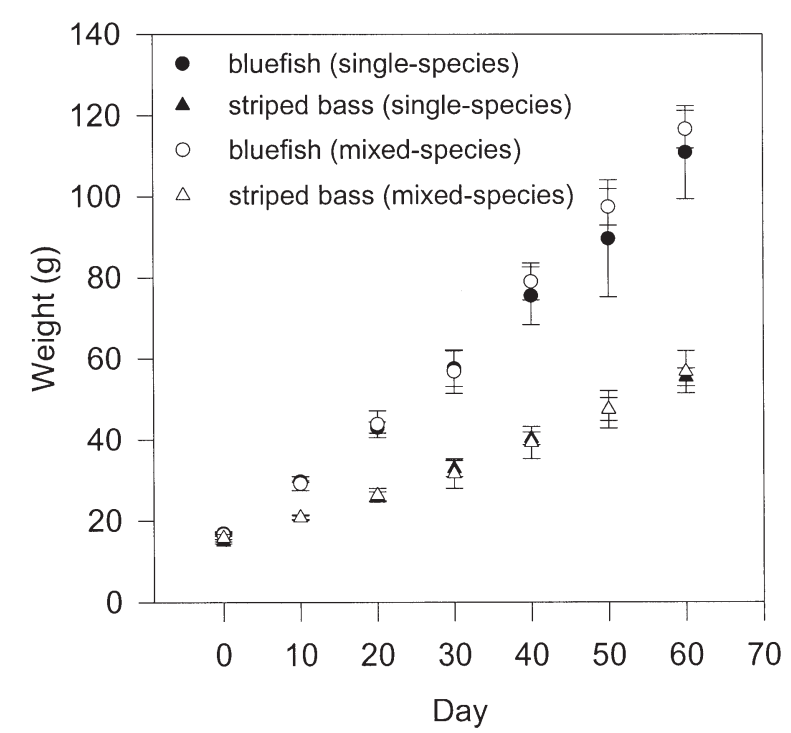

Fig. 5. Pomatomus saltatrix and Morone saxatilis. Mean $( \pm \mathrm{SE})$ individual fish weight vs day of growth experiment for bluefish and striped bass (in single- and mixed-species experiments)

to examine diets of bluefish that were captured within the same bays and on the same dates as the striped bass. We found that diets of age-0 bluefish were similar to those recorded in past studies in nearby bays; dominant prey included Atlantic silversides and bay anchovy (Juanes \& Conover 1995).

Habitat and diet overlap

Although spring-spawned bluefish and age-1 striped bass coexist in the same bays during the summer, these fish did not appear to overlap in habitat use at the spatial scale of our seine hauls. Similarly, Hartman (1965) found that juvenile salmonids (coho salmon and steelhead) occupied the same coastal stream habitats but were found in different microhabitats during the spring and summer (e.g. pools vs riffle). The bays we studied were turbid, and monitoring of fish in different habitats was not possible. Low habitat-overlap values could result from bluefish and striped bass using separate microhabitats or not using a specific habitat at the same time. Age-1 striped bass may avoid areas where spring-spawned bluefish occur given that bluefish are an important predator on age-0 striped bass during their first summer (Buckel et al. 1999). Winemiller (1989) showed that piranhas may restrict access of other piscivore species to open-water habitats during the day in the Venezuelan llanos.

There are limitations to our habitat-overlap analysis. First, because our sampling was only done during daylight hours we may have missed habitat overlap at

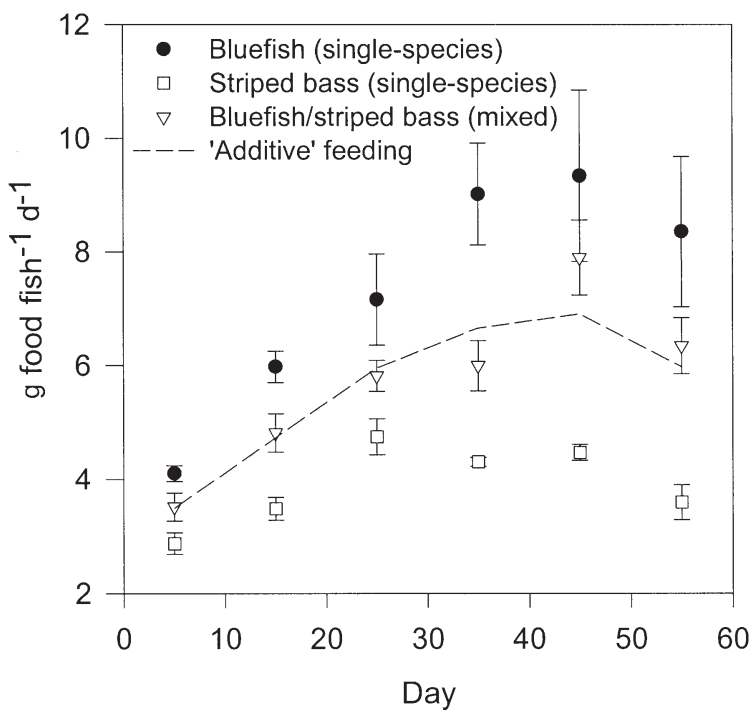

Fig. 6. Pomatomus saltatrix and Morone saxatilis. Mean $( \pm \mathrm{SE})$ absolute ingestion rate vs day of growth experiment for bluefish and striped bass in single-species and mixed-species experiments. 'Additive' feeding is the mean of single-species ingestion rates for bluefish and striped bass (see 'Materials and methods' for explanation)

other periods of the diel cycle. Bluefish are known to feed during daylight and crepuscular time periods (Buckel \& Conover 1997). Little is known about the diel feeding chronology of age-1 striped bass; however, we did find fresh prey in striped bass stomachs suggesting at least some diurnal foraging. Secondly, our sampling was restricted to the nearshore environment and overlap may have occurred in offshore habitats in these embayments. Bluefish juveniles are known to use the nearshore environment for feeding (Buckel \& Conover 1997), but specific areas where juvenile striped bass feed in the wild are not well defined.

The degree of habitat overlap may be size-dependent. Spring-spawned bluefish and age-1 striped bass had a higher overlap in October of 1997 and 1998, when sizes were similar. We would expect this pattern if similar-sized bluefish and striped bass had overlapping diets, but diet overlap data for October do not support this explanation.

Diet overlap between spring-spawned bluefish and age-1 striped bass was low. This was not only due to differences in the magnitude of piscivory between bluefish and striped bass, but also due to differences in piscine prey type: bluefish fed more on pelagic fish (e.g. bay anchovy) whereas striped bass included benthic fish prey (e.g. killifish) in their diet. Other studies which have compared bluefish diet with co-occurring species have similar findings. Age-0 bluefish had low diet overlap with several age classes of striped bass (including age-1) in Chesapeake Bay (Hartman \& 
Brandt 1995). Lucena et al. (2000) found little overlap between bluefish and a sciaenid species in southern Brazil during summer and fall. The 2 species did exploit the same prey during the winter; however, the authors felt that competition was unlikely because of the high abundance of the mutual prey species Engraulis anchoita (Lucena et al. 2000).

We examined for diet overlap when bluefish and striped bass were sympatric. Differences in resource use when 2 species are sympatric and allopatric can indicate competitive interactions (Wootton 1998). Age-0 bluefish use New York Bight bays during summer and early fall, while juvenile striped bass are associated with these systems throughout the year. Striped bass diets can be examined in the absence of bluefish to determine if resource use differs (e.g. more fish prey). A study of striped bass diets from November through April in the lower Hudson River estuary (mouth of the Hudson River and upper New York Harbor) showed that the diet of striped bass (200 to $299 \mathrm{~mm}$ ) was dominated by invertebrates ( 80\%), with the remainder of the diet composed of fishes (Dunning et al. 1997). This pattern was also observed for overwintering age-0 striped bass $(<200 \mathrm{~mm}$ ) (Dunning et al. 1997, Hurst \& Conover 2001). Juvenile striped bass do not increase their feeding on fish prey during times of the year when bluefish are absent (although seasonal changes in prey resources could confound results); this provides further evidence that contemporary competitive interactions between juvenile striped bass and bluefish are not likely.

It is difficult to determine if competition is important based on field overlap data because different conclusions can be drawn from the same data (Colwell \& Futuyma 1971). For example, one interpretation of our niche overlap data is that there is little chance for competition between juvenile striped bass and bluefish because these predators have low overlap in habitat and diet. However, an alternative interpretation could be that these 2 species exhibit resource partitioning because of historical competitive interactions (e.g. 'ghosts of competition past': Crowder 1986). One way to resolve these opposing conclusions is by conducting experimental manipulations (Colwell \& Futuyma 1971, Crowder 1986, Ross 1986).

\section{Growth experiments}

Field data were used to design the laboratory growth experiment. Field collections provided evidence that the only prey resource shared was fishes. Additionally, fish prey did not appear to be a limited resource (in an absolute sense) as small piscine prey items were always at least 10 times more abundant than bluefish and striped bass. Based on these observations, unlimited fish prey was provided during the laboratory experiment (see 'Materials and methods'). We hypothesized that aggressive or territorial behavior from a dominant would cause decreased growth in the subordinate.

Growth data from the laboratory experiment provided no evidence for interference competition between the 2 species. Spring-spawned bluefish and age-1 striped bass from the mixed-species treatment grew at the same rates as their conspecifics in the single-species treatments. Although size is known to be a dominant factor in competitive interactions (Sabo \& Pauley 1997), striped bass growth was not influenced even when bluefish were nearly twice the weight of the striped bass in the mixed-species tank. Growth depensation in either bluefish or striped bass did not occur. Overall, there was no evidence for a competitive dominant during the experiment.

In contrast to our laboratory findings, past experimental work in freshwater environments have found competition using mixed- and single-species treatment comparisons. Werner \& Hall (1976) found that both habitat use and growth differed in 3 Lepomis species between mixed- and single-species treatments in small ponds. Although 'habitat use' was not quantified in our experimental tanks, qualitative observations found that bluefish occupied the upper portion of the water column while striped bass were more bottom-oriented, particularly near the base of the stand pipes in both the single- and mixed-species tanks. Persson (1987) found that the presence of roach caused lowered perch growth rates relative to perch growth when held in a single-species treatment. This resulted from resource limitation due to interspecific competition.

We assumed that fish prey was unlimited in New York Bight marine bays, but this was not tested explicitly. Exploitative competition may occur in years when the abundance of small piscine prey is low. Relative to age-0 bluefish, Scharf (2001) has shown that age-1 striped bass have lower capture success on small piscine prey; furthermore, they are not capable of capturing relatively large piscine prey. In a laboratory experiment with limited prey similar to the interference competition experiment described above, bluefish grew more than expected and striped bass grew less than expected compared to controls (Scharf 2001). Testing the possibility of prey limitations in New York Bight estuaries will require identification of the prey types, sizes, and densities that are required to meet the predatory demands of a range of striped bass and bluefish (and other piscivores) sizes and densities.

Long-term monitoring data suggest that exploitative competition between bluefish and striped bass juveniles is not likely; annual field estimates of the growth 
rate of the 2 species were not related to the abundance of potential competitors. The use of such 'natural experiments' (Crowder 1986) has proven useful in identifying competitive interactions. For example, a negative correlation between annual young-of-theyear largemouth bass growth and density of small bluegill collected from Michigan lakes contributed evidence that interspecific competition exists between these 2 species (Olson et al. 1995).

Ingestion rate data allowed us to examine for interactions such as facilitation or interference. There were no differences in ingestion rates between the mixedand single-species 'additive' treatment in our experiment, confirming that interference did not occur. Facilitation occurs when one species makes a prey more susceptible to a second species. For example, bluefish may cause prey that are using the surface as a refuge to move to the bottom, where prey may be more vulnerable to striped bass attack (e.g. drive prey downward: Sih 1993). The ingestion and growth rate data from the laboratory experiment show that facilitation did not occur between juvenile bluefish and striped bass.

\section{Implications}

There is considerable interest in understanding the mechanisms that affect population dynamics of bluefish in several areas of the world (see Juanes et al. 1996). On the east coast of the US, opposite patterns in landings of striped bass and bluefish are hypothesized to result from biological interactions between the 2 species (Fig. 1). Buckel et al. (1999) found that age-0 bluefish are important predators on age-0 striped bass in the Hudson River estuary. However, this does not appear to be an important interaction in Chesapeake Bay (Hartman \& Brandt 1995) and is not likely a factor influencing patterns in striped bass landings in the coastal fishery. Our results suggest that competition between juvenile striped bass and bluefish is unlikely to drive these patterns in population abundance.

Competition limits growth in the juvenile stages (in which prey are invertebrates) of piscivorous species in some freshwater systems (Persson \& Greenberg 1990, Olson et al. 1995). These juveniles are outcompeted by more abundant fish species which feed on invertebrate prey. These negative competitive effects are relaxed after the ontogenetic switch to fish prey (Persson \& Greenberg 1990, Olson et al. 1995). In the system we studied, there was no evidence for competition in the juvenile stage; however, adult bluefish and striped bass may have a higher overlap in diet as striped bass become more piscivorous. In contrast to the freshwater competitive interactions described above, bluefish and striped bass occupy a similar trophic level as adults. Older age classes ( $\geq$ age- 2 striped bass and $\geq$ age-0 bluefish) may have increased overlap in resources and a higher potential for competitive interactions. For example, the highest diet overlap values found between bluefish and striped bass in Chesapeake Bay was between age 3+ striped bass and age-1 and age- 2 bluefish (Hartman \& Brandt 1995). Future research efforts should focus on determining the importance of interference and exploitative competition on the distribution patterns of adult bluefish and striped bass.

Acknowledgements. We thank personnel of the New York State Department of Environmental Conservation and the Behavioral Ecology Branch at the James J. Howard Marine Sciences Laboratory (NOAA/National Marine Fisheries Service) for assistance with fish collections and laboratory experiments. Special thanks to Michael Temple for help with stomach content analysis, Michael Fahay and Joe Vitaliano for assistance with prey identification, Jeffrey Pessutti for map preparation, and Allan Stoner for valuable input throughout the study. Critical reviews were provided by Thomas Hurst, Philip Darby, Allan Stoner, and 3 anonymous reviewers. This work was supported by a National Research Council-National Oceanic and Atmospheric Administration (NOAA) Research Associateship and a grant from the NOAA/National Marine Fisheries Service-Institute of Marine and Coastal Sciences at Rutgers University Bluefish/Striped Bass Dynamics program (to J.A.B.).

\section{LITERATURE CITED}

Anonymous (1998) Amendment 1 to the bluefish fishery management plan. Mid-Atlantic Fishery Management Council, Dover, DE

Berggren TJ, Lieberman JT (1978) Relative contribution of Hudson, Chesapeake, and Roanoke striped bass, Morone saxatilis, stocks to the Atlantic coast fishery. Fish Bull (Wash DC) 76:335-345

Boynton WR, Polgar TT, Zion HH (1981) Importance of juvenile striped bass food habits in the Potomac estuary. Trans Am Fish Soc 110:56-63

Buckel JA, Conover DO (1997) Movements, feeding periods, and daily ration of piscivorous young-of-the-year bluefish,Pomatomus saltatrix, in the Hudson River estuary. Fish Bull (Wash DC) 95:665-679

Buckel JA, Conover DO, Steinberg ND, McKown KA (1999) Impact of age-0 bluefish (Pomatomus saltatrix) predation on age- 0 fishes in the Hudson River estuary: evidence for density-dependent loss of juvenile striped bass (Morone saxatilis). Can J Fish Aquat Sci 56:275-287

Bystroem P, Persson L, Wahlstroem E (1998) Competing predators and prey: juvenile bottlenecks in whole-lake experiments. Ecology 79:2153-2167

Colwell RK, Futuyma DJ (1971) On the measurement of niche breadth and overlap. Ecology 52:567-576

Cooper JE, Rulifson RA, Isely JJ, Winslow SE (1998) Food habits and growth of juvenile striped bass, Morone saxatilis, in Albemarle Sound, North Carolina. Estuaries 21: 307-317

Crowder LB (1986) Ecological and morphological shifts in 
Lake Michigan fishes: glimpses of the ghost of competition past. Environ Biol Fishes 16:147-157

Davis BM, Todd TN (1998) Competition between larval lake herring (Coregonus artedi) and lake whitefish (Coregonus clupeaformis) for zooplankton. Can J Fish Aquat Sci 55: 1140-1148

Dunning DJ, Waldman JR, Ross QE, Mattson MT (1997) Use of Atlantic tomcod and other prey by striped bass in the lower Hudson River estuary during winter. Trans Am Fish Soc 126:857-861

Fabrizio MC (1987) Growth-invariant discrimination and classification of striped bass stocks by morphometric and electrophoretic methods. Trans Am Fish Soc 116:728-736

Gardinier MN, Hoff TB (1982) Diet of striped bass in the Hudson River estuary. NY Fish Game J 29:152-165

Gotelli NJ, Entsminger GL (2001) EcoSim: null models software for ecology. Version 6. Acquired Intelligence Inc. \& Kesey-Bear. Burlington, VT 05465. (Available at: http:// homepages.together.net/ gentsmin/ecosim.htm

Hartman G (1965) The role of behaviour in the ecology and interaction of underyearling coho salmon (Oncorhynchus kisutch) and steelhead trout (Salmo gairdneri). J Fish Res Board Can 22:1035-1081

Hartman KJ, Brandt SB (1995) Trophic resource partitioning, diets, and growth of sympatric estuarine predators. Trans Am Fish Soc 124:520-537

Hixon MA (1980) Competitive interactions between California reef fishes of the genus Embiotoca. Ecology 61: 918-931

Hurst TP, Conover DO (2001) Diet and consumption of overwintering YOY striped bass, Morone saxatilis, in the Hudson River. Fish Bull (Wash DC) 99:545-553

Juanes F, Conover DO (1995) Size-structured piscivory: advection and the linkage between predator and prey recruitment in young-of-the-year bluefish. Mar Ecol Prog Ser 128:287-304

Juanes F, Hare JA, Miskiewicz AG (1996) Comparing early life history strategies of Pomatomus saltatrix: a global approach. Mar Freshw Res 47:365-379

Lucena FM, Vaske T Jr, Ellis JR, O'Brien CM (2000) Seasonal variation in the diets of bluefish, Pomatomus saltatrix (Pomatomidae) and striped weakfish, Cynoscion guatucupa (Sciaenidae) in southern Brazil: implications of food partitioning. Environ Biol Fishes 57:423-434

Manooch CS III (1973) Food habits of yearling and adult striped bass, Morone saxatilis (Walbaum), from Albemarle Sound, North Carolina. Chesapeake Sci 14:73-86

Markle DF, Grant GC (1970) The summer food habits of young-of-the-year striped bass in three Virginia Rivers. Chesapeake Sci 11:50-54

McBride RS, Conover DO (1991) Recruitment of young-ofthe-year bluefish Pomatomus saltatrix to the New York Bight: variation in abundance and growth of spring- and summer-spawned cohorts. Mar Ecol Prog Ser 78:205-216

McKown KA, LoBue CP, Gelardi R (1999) An investigation of the movements and growth of the 1996 Hudson River year class. A study of striped bass in the marine district of New York VII. New York State Department of Environmental Conservation, East Setauket

Editorial responsibility: Kenneth Sherman (Contributing Editor), Narragansett, Rhode Island, USA
Olson MH, Mittelbach GG, Osenberg CW (1995) Competition between predator and prey: resource-based mechanisms and implications for stage-structured dynamics. Ecology 76:1758-1771

Persson L (1987) Competition-induced switch in young of the year perch, Perca fluviatilis: an experimental test of resource limitation. Environ Biol Fishes 19:235-239

Persson L, Greenberg LA (1990) Juvenile competitive bottlenecks: the perch (Perca fluviatilis)-roach (Rutilus rutilus) interaction. Ecology 71:44-56

Prout MW, Mills EL, Forney JL (1990) Diet, growth, and potential competitive interactions between age- 0 white perch and yellow perch in Oneida Lake, New York. Trans Am Fish Soc 119:966-975

Robertson DR (1995) Competitive ability and the potential for lotteries among territorial reef fishes. Oecologia 103: $180-190$

Ross ST (1986) Resource partitioning in fish assemblages: a review of field studies. Copeia 1986:352-388

Sabo JL, Pauley GB (1997) Competition between streamdwelling cutthroat trout (Oncorhynchus clarki) and coho salmon (Oncorhynchus kisutch): effects of relative size and population origin. Can J Fish Aquat Sci 54:2609-2617

Scharf FS (2001) The influence of behavior on size-structured predator-prey interactions: prey susceptibility, predator selection, and population-level consequences for juvenile estuarine fishes. PhD dissertation, University of Massachusetts, Amherst

Schoener TW (1970) Non-synchronous spatial overlap of lizards in patchy habitats. Ecology 51:408-418

Secor DH, Trice TM, Hornick HT (1995) Validation of otolith-based ageing and a comparison of otolith and scalebased ageing in mark-recaptured Chesapeake Bay striped bass, Morone saxatilis. Fish Bull (Wash DC) 93: $186-190$

Sih A (1993) Effects of ecological interactions on forager diets: competition, predation risk, parasitism and prey behavior. In: Hughes RN (ed) Diet selection: an interdisciplinary approach to foraging behavior Blackwell Scientific Publications, Oxford, p 182-211

Waldman JR, Richards RA, Schill WB, Wirgin I, Fabrizio MC (1997) An empirical comparison of stock identification techniques applied to striped bass. Trans Am Fish Soc 126:369-385

Wallace RK Jr (1981) An assessment of diet-overlap indexes. Trans Am Fish Soc 110:72-76

Weis HM (1995) Marine animals of Southern New England and New York. Bulletin 115, Sweet Printing Company, Glastonbury, CT

Werner EE, Hall DJ (1976) Niche shifts in sunfishes: experimental evidence and significance. Science 191:404-406

Winemiller KO (1989) Ontogenetic diet shifts and resource partitioning among piscivorous fishes in the Venezuelan ilanos. Environ Biol Fish 26:177-199

Winemiller KO, Pianka ER (1990) Organization in natural assemblages of desert lizards and tropical fishes. Ecol Monogr 60:27-55

Wootton RJ (1998) Ecology of teleost fishes. Kluwer Academic Publishers, Dordrecht

Submitted: May 1, 2001; Accepted: December 3, 2001

Proofs received from author(s): May 3, 2002 